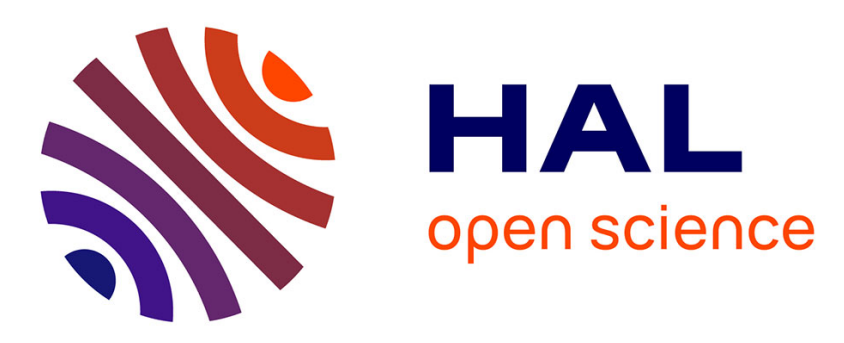

\title{
Comparison of three downscaling methods in simulating the impact of climate change on the hydrology of Mediterranean basins
}

Pere Quintana Seguí, Aurélien Ribes, Eric Martin, Florence Habets, Julien Boé

\section{To cite this version:}

Pere Quintana Seguí, Aurélien Ribes, Eric Martin, Florence Habets, Julien Boé. Comparison of three downscaling methods in simulating the impact of climate change on the hydrology of Mediterranean basins. Journal of Hydrology, 2010, Volume 383 (Issues 1-2), pp.111-124. 10.1016/j.jhydrol.2009.09.050 . hal-00459505

\section{HAL Id: hal-00459505}

https: / hal-mines-paristech.archives-ouvertes.fr/hal-00459505

Submitted on 1 Mar 2010

HAL is a multi-disciplinary open access archive for the deposit and dissemination of scientific research documents, whether they are published or not. The documents may come from teaching and research institutions in France or abroad, or from public or private research centers.
L'archive ouverte pluridisciplinaire HAL, est destinée au dépôt et à la diffusion de documents scientifiques de niveau recherche, publiés ou non, émanant des établissements d'enseignement et de recherche français ou étrangers, des laboratoires publics ou privés. 


\title{
Comparison of three downscaling methods in simulating the impact of climate change on the hydrology of Mediterranean basins
}

\author{
P. Quintana Seguí,a,b, A. Ribes ${ }^{\mathrm{b}}$, E. Martin ${ }^{\mathrm{b}}$, F. Habets ${ }^{\mathrm{c}}$, J. Boéd \\ ${ }^{a}$ Observatori de l'Ebre (Universitat Ramon Llull - CSIC), Horta Alta 38, 43520 \\ Roquetes, Spain. \\ ${ }^{b}$ CNRM-GAME (Météo-France CNRS), 42 av. G. Coriolis, 31057 Toulouse Cedex, \\ France. \\ ${ }^{c}$ UMR-SISYPHE ENSMP, Centre de Géosciences, 35 rue St Honoré, 77305 \\ Fontainebleau, France. \\ ${ }^{d}$ Atmospheric and Oceanic Sciences Department, University of California Los Angeles, \\ PO Box 951565, California 90095-1565, USA.
}

\begin{abstract}
Studies of the impact of climate change on water resources usually follow a top to bottom approach: a scenario of emissions is used to run a GCM simulation, which is downscaled (RCM and/or stastistical methods) and bias-corrected. Then, this data is used to force a hydrological model. Seldom, impact studies take into account all relevant uncertainties. In fact, many published studies only use one climate model and one downscaling technique. In this study, the outputs of an atmosphere-ocean regional climate model are downscaled and bias-corrected using three different techniques: a statistical method based on weather regimes, a quantile-mapping method and the method of the anomaly. The resulting data are used to force a distributed hydrological model to simulate the French Mediterranean basins.
\end{abstract}

\footnotetext{
${ }^{*}$ Corresponding author

Email address: pquintana@obsebre.es (P. Quintana Seguí)
} 
These are characterized by water scarcity and an increasing human pressure, which cause a demand in assessments on the impact of climate change hydrological systems. The purpose of the study is mainly methodological: the evaluation of the uncertainty related to the downscaling and bias-correction step. The periods chosen to compare the changes are the end of the 20th century (1970-2000) and the middle of the 21st century (2035-2065). The study shows that the three methods produce similar anomalies of the mean annual precipitation, but there are important differences, mainly in terms of spatial patterns. The study also shows that there are important differences in the anomalies of temperature. These uncertainties are amplified by the hydrological model. In some basins, the simulations do not agree in the sign of the anomalies and, in many others, the differences in amplitude of the anomaly are very important. Therefore, the uncertainty related to the downscaling and bias-correction of the climate simulation must be taken into account in order to better estimate the impact of climate change, with its uncertainty, on a specific basin. The study also shows that according to the RCM simulation used and to the periods studied, there might be significant increases of winter precipitation on the Cévennes region of the Massif Central, which is already affected by flash floods, and significant decreases of summer precipitation in most of the region. This will cause a decrease in the average discharge in the middle of the 21 st in most of the gauging stations studied, specially in summer. Winter and, maybe spring, in some areas, are the exception, as discharge may increase in some basins.

Key words: Hydrology, simulation, regional climate, impacts, Mediterranean, uncertainty, downscaling 


\section{Introduction}

The Mediterranean basin is a quasi-closed sea with a marked orography on its periphery and a high urbanization of its coastline. Its climate is characterized by mild winters and hot and dry summers. The marked orography often triggers intense events that may cause flash floods and the hot and dry weather in summer causes low flows to be long and severe. In this context, for planning purposes, it is important to evaluate the possible impacts of climate change on water resources in such a region.

Global climate models (GCM) are the main tool used to study the future climate. According to Giorgi and Lionello (2008), the study of several GCM simulations shows "a robust and consistent picture of climate change over the Mediterranean emerges, consisting of a pronounced decrease in precipitation, especially in the warm season, except for the northern Mediterranean areas (e.g. the Alps) in winter.". It is also expected that the variability increases. In fact, according to Giorgi (2006) the Mediterranean basin is one of the planet's hot-spots of climate change.

However, GCMs do not have enough resolution to study the regional and local scales. Their current resolution of $300 \mathrm{~km}$ (Solomon et al., 2007) misses most of the important relief surrounding the Mediterranean basin. Furthermore, at this scale, they are often biased. This obliges us to downscale the outputs of these models.

The usual strategy in impact studies has a top to bottom structure. Global socio-economic assumptions are made (Nakicenovic et al., 2000), which are then used to force GCMs, which are then downscaled and unbiased. This downscaling can be dynamical (computationally expensive) or statistical (less 
expensive) (Mearns et al., 1999). If the chosen method is dynamical, a limited area atmospheric model, which can simulate in more detail the climate on a smaller area, is forced at the edges of the domain by the outputs of a GCM (Hewitson and Crane, 1996). These models are known as regional climate models (RCM) and have a typical resolution of $50 \mathrm{~km}$ or $25 \mathrm{~km}$. Often, dynamical and statistical downscaling methods are presented as mutually exclusive, but, in fact, as it will be seen in further sections, they can be used together.

The resolution of a RCM is not enough for most hydrological models, thus they need to be further downscaled and bias-corrected (Christensen et al., $2008)$ to produce atmospheric forcings at the adequate resolution $(10 \mathrm{~km})$ (Wood et al., 2004). Thus it is necessary to further downscale the output of these models and to develop methods to reconstruct the regional climate in relation to climate on a larger scale.

In these studies, the emission scenario and the GCM are the main sources of uncertainty (Boé, 2007; Maurer and Hidalgo, 2008). But, unfortunately, each step of the downscaling procedure also has associated uncertainty. All these uncertainties add up and constitute a cascade of uncertainty that must be taken into account. Thus, a complete impact study must look at all kinds of uncertainty. Many studies, have focused on the uncertainty related to the GCM (Hamlet and Lettenmaier, 1999; Maurer and Duffy, 2005; Wilby et al., 2006; Christensen and Lettenmaier, 2007; Minville et al., 2008) but fewer studies have focused on uncertainties related to downscaling to the resolution of the impact model (Dibike and Coulibaly, 2005; Khan et al., 2006; Boé et al., 2007), which might also be important and is often neglected. 
Within this study we look at the impacts of climate change on the French Mediterranean basins. Our goal is to force the hydrological model SIM with three atmospheric forcings representing the climate of the future. These forcings are build from the same RCM simulation using three different methods of downscaling and bias-correction. This should enable us to estimate the hydrological response to climate change, and to estimate the uncertainties related to the last step of downscaling and bias-correction of the climate simulation.

\section{The French Mediterranean context}

[Figure 1 about here.]

This article is focused on the French Mediterranean region. Figure 1 shows the French Mediterranean basin, plus some rivers that do not reach the Mediterranean sea but are Mediterranean in climatological terms. These are situated on the Massif Central.

The largest French Mediterranean basin is the Rhône. Two of the main tributaries of the Rhône are alpine and have a very important nival component. These tributaries are also heavily influenced by hydropower production. But, in our context, we are more interested in the small basins that are tributaries of the Rhône or flow into the Mediterranean sea and are of Mediterranean climate. To name a few: Aude, Hérault, Gardon, Ardèche, Huveaune and Var. These basins have sizes ranging from $373 \mathrm{~km}^{2}$ for the Huveaune up the $6074 \mathrm{~km}^{2}$ for the Aude and play a very important role for the water supply for agriculture, industry and cities, as well as to contribute freshwater to the sea. In some of these basins, there are some karstic sys- 
75

tems, which are difficult to model, but are important for water supply. The French Mediterranean basins undergo long dry periods and may therefore be especially susceptible to the effects of climate change.

[Figure 2 about here.]

[Table 1 about here.]

Figure 2 shows the climatology of temperature and precipitation for the period 1970-2000 on the area. Column SFR of Table 1 (section Precipitation) shows the observed averages of annual and seasonal precipitation. In the coastal areas, annual precipitation does not exceed $1.4 \mathrm{~mm} \mathrm{~d}^{-1}$. Precipitation increases with altitude, in particular on the northern part of the French Alps, Jura and Cévennes (up to $4.1 \mathrm{~mm} \mathrm{~d}^{-1}$ ). Precipitation on the Cévennes is mainly due to Mediterranean storms that occur from September to December. These storms are intense and are often associated to catastrophic floodings. The evolution of these storms in the context of climate change is of high interest.

\section{Methodology}

In this study, three different methods are used to downscale and biascorrect the outputs of one single RCM simulation, using a gridded database of observations. In the next sections, the gridded database, the RCM and the downscaling methods are described.

\subsection{Gridded database of observations}

SAFRAN (Durand et al., 1993) produces an analysis of near surface atmospheric parameters at a resolution of $8 \mathrm{~km}$ using observations from the 
automatic, synoptic and climatological networks of Météo-France and a first guess from a large scale operational weather prediction model. The analysis is made using optimal interpolation for most of the parameters, but for incoming solar radiation and downward infrared radiation, SAFRAN uses a radiative transfer scheme (Ritter and Geleyn, 1992). A more detailed description of SAFRAN is found in Quintana-Seguí et al. (2008).

\subsection{Climate scenario}

The model SAMM (Sea Atmosphere Mediterranean Model) Somot et al. (2008) is a coupling between the atmospheric model ARPEGE-Climate (Gibelin and Déqué, 2003) and the model of the Mediterranean Sea OPAMED (Somot, 2005; Somot et al., 2006). SAMM is the first AORCM (Atmosphere-Ocean Regional Climate Model) dedicated to the Mediterranean. The maximum resolution of the ARPEGE model on the Mediterranean region is of $50 \mathrm{~km}$, OPAMED's is about $10 \mathrm{~km}$. For the 21st century the simulation is done using the scenario of emissions IPCC SRES A2 (high economic and demographic growth, Nakicenovic et al. (2000)). The simulation covers a period of 139 years: 1961-2099.

Regarding temperature at $2 \mathrm{~m}$, the anomalies (2070-2099 vs 1961-1990) obtained by this model are consistent with previous estimates (PRUDENCE ${ }^{1}$ ). In summer, increases of 4 to $5{ }^{\circ} \mathrm{C}$ are expected in south-eastern France. For rainfall, an increase in winter precipitation in northern Europe and a decrease in the Mediterranean region are expected. The model shows, in the area of interest, a decrease of $0.5 \mathrm{~mm} \mathrm{~d}^{-1}$ in summer, which is important considering

\footnotetext{
${ }^{1}$ http://prudence.dmi.dk
} 
the average, which in summer is between 1 and $2 \mathrm{~mm} \mathrm{~d}^{-1}$.

\subsection{Downscaling methods \\ 3.3.1. Statistical downscaling}

The first method used for the downscaling of the RCM was developed by Boé et al. (2006); Boé (2007); Pagé et al. (2008). This method is a weather typing approach in which the large scale variables simulated by the model (surface pressure and temperature) are used to relate days from the future and days from the past according to their weather type. This allows to build a database of future climate based on fine scale information coming from an database of observations (Sec. 3.1). The learning period is 1981-2005.

First, a limited number of discriminant weather types for rainfall in France is established. This classification is done for three seasons (winter, springsummer and autumn). Between 8 and 9 weather types are defined for each season. To take into account the intra-type variations (which may be important), an index of precipitation is built using regressions between the distance of a day to the center of the type and the precipitation analyzed by SAFRAN. For temperature, an index over the domain is also calculated. This way, a day of the SAFRAN database is associated with each day simulated by the climate model, taking into account the weather type and the previously calculated indices. In addition, a further correction on the temperature can be made if the index of temperature of the day in SAFRAN is very different from the day simulated by the general circulation model (as in the end of the 21st century). The method was optimized to be applied to the whole of France, not only the South-East. Therefore the results in this region are not optimal, as its climate has some particularities comparing to the rest of the 
country (it is more variable, dryer in summer, etc.).

This method has some limitations, which are characteristic of the statistical downscaling techniques. It is supposed that the large-scale variable is a good predictor of the variable of interest at fine-scale. Also, it is supposed that the link between these two variables is stable in a changing climate. This hypothesis is not verifiable and, in fact, it may be false. Finally, for precipitation, the method is not able to produce extreme phenomena outside those which are present in the database of observations, which covers a the period 1970-2008 (but the hydrological model, forced with such downscaled data, can produce discharges outside historical values because the frequencies will certainly change).

However, the method has some important advantages too. All the variables of the chosen day are coherent between each other and the daily cycle of each variable is realistic. Within the same day, there is a very good spatial coherence. Finally, the method does not need a RCM. It can be directly applied to a GCM.

We will refer to this method as WT (weather typing).

\subsubsection{Quantile mapping}

The second method used to downscale the climate simulation is based on quantile mapping (QM) (Wood et al., 2004; Déqué et al., 2007; Boé et al., 2007). Comparing to the previous one, the main difference of this method is that it uses the model outputs for all the variables at the fine scale (those needed to force SIM: precipitation, temperature, wind speed, humidity, solar radiation and downward atmospheric radiation). It corrects their distribution to eliminate systematic errors. If the previous method ignored the outputs 
of the model at the fine scale and used the large scale variables, with this one the opposite is done, the information provided by the model at the large scale is ignored and the information at the small scale is used.

The correction is made at the resolution of SAFRAN $(8 \mathrm{~km})$. For each cell, a correction is calculated for each percentile of the distribution of each variable of interest at the daily time step, by comparing the observed distribution to that of the closest model cell:

- The correction was calculated for each season for the period August 1970 - July 2006.

- Between percentiles and at the extremes, the correction function is linearly interpolated.

- To interpolate the variables to the hourly time step (from the daily time step), which is necessary for the hydrological model, a mean daily cycle is calculated for each variable using SAFRAN. For the temperature, the correction is calculated for the daily maximum and minimum, hence the daily cycle is modified according to these two variables.

- Finally, some tests were done to verify that the resulting forcings are physically realistic, for example, that the values of incoming solar radiation are within physical limits, taking into account the solar constant and the attenuation by the atmosphere.

This method relies on the hypothesis that the correction function is constant in time, which is not verifiable. In particular, the method does not distinguish the causes of the bias of the model. For example, the bias of 
precipitation of the climate model ARPEGE depends on the type of atmospheric circulation. If this circulation changes in the future, that seems very likely, the correction may be inappropriate. Unlike the previous method, the QM method ignores the outputs of the climate model that are simulated the best (large scale) and each variable is corrected separately. Consequently to this last point, there is no physical coherence between the different corrected variables. However, to calculate corrections of one variable, conditioned to the corrections of other variables, a new hypothesis would need to be established, which might also be arbitrary and introduce new problems. Another key point is that the method does not correct the spatial pattern of the model (in percentile), so that, for example, the area where a 99th percentile rain takes place is as big as the model's grid cell, which is not realistic enough, even if the intensities are corrected. Furthermore, the extrapolation of the function to the extremes is based on an arbitrary assumption (linearity), the daily cycles are not very realistic, and the method should only be used for high resolution simulations, which is the case in our study $(50 \mathrm{~km})$.

But the advantages are also important. The method is quite simple and easy to implement. For present climate, the method does not degrade the variables that are correctly simulated by the model and, also for present climate, there is no bias at all over the reference period (1970-2000).

\subsubsection{Anomaly}

This last method is the simplest one of the methods used in this study. It consists of superposing the mean climatological anomaly estimated using a GCM or RCM to a high resolution observed dataset. This method has been widely used in the literature, therefore it allows comparison with previous 
studies (Hamlet and Lettenmaier, 1999; Etchevers et al., 2002; Caballero et al., 2007; Jyrkama and Sykes, 2007; van Roosmalen et al., 2009) and the evaluation of the gains obtained in using more elaborated downscaling methods. From now on, the method will be called AN.

The method was implemented as follows:

- The anomalies were calculated for temperature, precipitation, humidity, wind speed and atmospheric IR radiation.

- The anomalies were calculated comparing the periods: 2035-2065 and 1970-2000.

- They were calculated on a monthly basis.

- Relative anomalies were used. The ratio was calculated as follows : $r=\langle x\rangle_{\text {future }} /<x>_{\text {present }}$, where $x$ is the variable of interest. Afterwards the ratio was applied to the SAFRAN series of present climate.

- The anomaly of temperature was calculated for the daily maximum and minimum. A linear interpolation between the ratio of the maximum and the minimum was used to correct each value of temperature of the corresponding day. The anomaly was calculated in Kelvin.

- The anomaly of precipitation was calculated for total precipitation. Afterwards, the solid and liquid phases where separated using temperature. If $T>0,7^{\circ} \mathrm{C}$, then the precipitation was liquid, otherwise, solid. 
- After the anomaly of specific humidity was calculated, the series were corrected, using temperature, to avoid it to be higher than the value at saturation.

The method, as described is very simple to implement, but its limitations are important: only the mean climatological change is taken into account and the spatial variability is only taken into account at the resolution of the climate model. As a consequence, when using this method, only changes on the mean can be studied, the study of extremes and variability are therefore excluded.

\subsubsection{Validation}

[Figure 3 about here.]

[Figure 4 about here.]

Precipitation. Table 1 compares the annual and seasonal averages for the region produced by QM and WT with SAFRAN. QM, as expected, reproduces the same averages as SFR, on the contrary, WT is dryer for all seasons $(-7 \%$ for the annual average, $-9 \%$ in autumn). Figure 3 shows the geographical distribution of the differences in mean annual precipitation between the WT method and SAFRAN. It shows that the greater differences are located on the relief of the Massif Central and are within the range $(-1,-0.5) \mathrm{mm} \mathrm{d}^{-1}$, which is around $(-20,-8) \%$ depending on the grid cell. Therefore, the dryness of WT is mainly due to the method's lack of skill to reproduce the precipitation patterns in this area, which certainly is related to the difficulty of the method to discriminate the synoptic situations that produce high precipitation in this region. This is confirmed by panel (a) of Figure 4, which shows 
that the probability of having intense precipitations is smaller according to WT than to QM and SAFRAN. Panels (b) and (c) show that WT has difficulties to reproduce both long dry and wet spells and that QM overestimates wet spells. This might be due to the fact that the spatial scale of precipitation events in this region is smaller than the size of the grid cell of the RCM or, simply, because the model does not reproduce the wet spells well.

Temperature. Table 1 shows that, for the period 1970-2000, QM is cooler than SAFRAN $\left(-0.4{ }^{\circ} \mathrm{C}\right)$ and $\mathrm{WT}$ is warmer $\left(+0.4^{\circ} \mathrm{C}\right)$. The differences are not very important, but can be considered surprising in the case of QM, as it is expected that QM to reproduce the distribution of SAFRAN. This bias is probably due to the choice of 1970-2006 as the training period for QM, that differs from 1970-2000, that is used for the comparison.

\subsubsection{Conclusion}

The assumptions and hypotheses made when applying these methods are very different, specially when comparing WT with the other two methods. These hypotheses are often difficult to verify and sometimes have obvious weaknesses. If the results obtained are comparable, it will be a sign of robustness, otherwise, it will be a sign that more emphasis must be done on the uncertainty related to the downscaling methods.

\section{Description of the hydrological model}

In this study, a recent version (Quintana Seguí et al., 2009) of the SAFRANISBA-MODCOU (SIM) model (Habets et al., 2008) is used. This model is the result of combining the SAFRAN meteorological analysis, the ISBA surface 
scheme and the MODCOU hydrogeological model. Only the main features of the model are described in this paper.

ISBA (Noilhan and Planton, 1989; Boone et al., 1999) is a soil-vegetationatmosphere transfer (SVAT) scheme. It is used to simulate the exchanges in heat, mass and momentum between the continental surface (including vegetation and snow) and the atmosphere. There are several versions of ISBA, ranging from a two layer force-restore method (Deardorff, 1977), to a more detailed diffusion version (Boone, 2000; Habets et al., 2003). SIM is implemented using the three layered force-restore version (Boone et al., 1999) with the 3-layer snow scheme of Boone and Etchevers (2001). The version used in this study (Quintana Seguí et al., 2009) also includes an exponential profile of hydraulic conductivity to better reproduce the dynamics of water in the soil (Decharme et al., 2006).

The hydrogeological model MODCOU calculates the temporal and spatial evolution of the aquifer at several layers, using the diffusivity equation (Ledoux et al., 1989). Then it calculates the interaction between the aquifer and the river and finally it routes the surface water to the rivers and within the river using an isochronistic algorithm. It calculates river discharge with a time step of three hours. The time step used to calculate the evolution within the aquifer is 1 day. In the version of SIM used in this study, the aquifers are only simulated in two basins: the Seine (3 layers) and the Rhône (1 layer) basins.

\section{Results}

Two periods of 30 years were selected to compare present and future climate. For present climate, it was chosen to study the period August 1970 
- July 2000. The period selected for the future is: August 2035 - July 2065. The significance of the anomalies is evaluated using an adaptation of the Student test that does not require the assumption of the equality of the variances of the compared samples. This adaptation is often referred to as the Welch's test (Welch, 1947).

\subsection{Analysis of downscaled meteorological variables}

5.1.1. Precipitation

[Figure 5 about here.]

[Figure 6 about here.]

[Figure 7 about here.]

Table 1 compares the anomalies produced by the three methods. It shows that AN and QM always agree in the sign of the anomaly, whereas WT differs in winter. The three methods agree in a decrease of annual precipitation between $3 \%$ and $4 \%$. They also agree in a more important decrease of precipitation in summer (between $12 \%$ and 16\%). The differences are mainly found in winter, where WT presents a positive anomaly whereas the other two methods a negative one. In autumn WT presents no anomaly and AN, in the other extreme, an anomaly of $-6 \%$.

Figure 5 shows that AN and QM produce quite similar geographical patterns, which was expected, as QM can be regarded as an evolution of AN. These methods predict a diminution of precipitation on most of the region, but also an increase near the Mediterranean coast and the maritime Alps. These anomalies are only significant near the Massif Central and in a region between the Alps and the Rhône. On the other hand, the spatial structure of 
the mean calculated by WT is different. In this case, the anomaly is wetter on a larger area and dryer on the swiss part of the Alps. The changes are significant mainly in the upper alpine region, towards Switzerland, where the anomaly is negative. This first comparison shows that the differences between methods can be important.

The anomalies of precipitation produced by QM and AN are also similar for the four seasons. On the other hand, the spatial patterns of the anomalies produced by WT are quite different geographically, but their intensities are comparable to those of the other methods. Their geographical pattern is more similar in winter (Fig. 6) and autumn (not shown). In winter, it is expected that precipitation will increase in the southern part of the Mediterranean region, specially on the relief of the Massif Central, where the changes are significant (Fig. 7). The AN method is less sensitive to this change on the relief, as the changes are probably related to the strong events (extremes) usually found in this part of the basin. Another region where differences are important in winter, according to WT and QM, is the swiss part of the basin, but the changes are not significant. In spring (not shown), according to QM and AN, a significant diminution of precipitation is expected between the Cevennes and the Rhône river. In contrary, WT produces a different picture. In this case, the anomalies are positive in a large area, but they are not significant. Differences in sign are also found in autumn. During this period, as in spring, AN and QM are dryer than WT, which produces a positive anomaly over half of the region, but the anomalies are not significant for any of the methods. Summer (Fig. 6) is the period with more significant changes (Fig. 7), according to the three methods. The anomalies are mainly 
negative, but, again, the spatial structure of these anomalies is different, depending on the method used.

\subsubsection{Temperature}

The anomalies of temperature are very homogeneous throughout the region (not shown). For the annual average, the three methods show an important degree of coincidence (Table 1): the average anomaly for the whole region is almost identical (between $1.5^{\circ} \mathrm{C}$ and $1.7^{\circ} \mathrm{C}$ ). According to $\mathrm{WT}$, the anomaly is warmer in the northern part. According to AN the North-South gradient presents an opposite trend. The study of the summer average shows that the anomalies produced by $\mathrm{AN}$ and $\mathrm{QM}$ are more important than the anomaly of WT. In the first case, the average anomaly is of $2.2^{\circ} \mathrm{C}$ and in the second it is of $1.4^{\circ} \mathrm{C}$. These differences are mainly due to the choice of the temperature index in WT, which was calculated at the scale of Europe. SAMM produces an important increase of summer temperature in France, which contrasts with a milder increase in Europe, which is the reference increase for WT.

\subsection{Hydrological impacts}

5.2.1. Water balance

Table 1 shows the total runoff (the addition of surface and subsurface runoff) and evapotranspiration obtained by each of the simulations and aggregated to the whole area of interest. The context is of a diminution of precipitation, specially in summer and an increased precipitation, specially on the Cévennes area, in winter. Due to an increased temperature, evapotranspiration increases (except in summer, as there is not enough water available). This translates in a decrease of runoff, mainly in spring and sum- 
mer. The agreement in this respect is relatively good, specially in summer, but the magnitude of the change in spring goes from $-7 \%$ to $-15 \%$. For evapotranspiration, the relative anomalies are lower than for runoff, but the discrepancies between methods are evident: there is no agreement in the sign of the change for the annual mean. In fact, the methods only agree in the sign of spring and summer anomalies, but the differences in magnitude are important. In conclusion, the differences between methods are more important for runoff and evapotranspiration than for precipitation. Therefore, the hydrological model amplifies the uncertainties.

\subsubsection{Discharge}

[Figure 8 about here.]

[Figure 9 about here.]

[Figure 10 about here.]

[Figure 11 about here.]

The analysis starts on Figure 8, which shows histograms of the anomalies of discharge for all the stations. The three methods agree in that, for most of the stations, the anomaly of the annual average is negative or zero. In winter most of the anomalies are positive according to the three methods. AN is the simulation that presents more stations with positive anomaly. In spring there is some disagreement. On the one hand, according to AN, most stations will have negative anomalies. On the other hand, WT presents a more balanced picture. In summer the agreement is quite important, all the methods present anomalies that attain $-40 \%$, even $-50 \%$ in some cases. QM 
and $\mathrm{AN}$ are the driest. In autumn, the three methods present also a quite negative picture, but not as dry as in summer.

Figure 9 presents the geographical distribution of the anomalies of the annual average. On the first look, the three methods present a similar picture, specially on the Saône (the northern part of the Rhône basin), but there is less agreement on the rest of the region. AN presents the most different pattern, as it shows negative anomalies on most of the Massif Central. On the contrary, QM and WT present points of positive anomaly (up to 30\%) on some basins of the Massif Central. According to WT, the area of positive anomaly on the Massif Central is larger and also presents some positive anomalies on the south eastern extreme of the area. WT disagrees with the other methods on the east part of the region, where it is dryer. If the stations are compared one to one, there are differences in sign in some stations and differences in magnitude that can attain 30\%. These uncertainties are important.

Figure 10 shows the seasonal anomalies for winter and summer (autumn and spring are not shown, but they are described in the text). The patterns are more similar in summer and winter, and less in autumn and spring. Fig. 11 shows the significance of the changes. In winter, there are positive anomalies on many stations. AN presents some important positive anomalies $(>80 \%)$ and WT presents more moderate changes. But these anomalies are not very significant. In spring, there are some important differences in sign on the area of the Massif Central and in the South East part of the region. According to AN the anomalies are significant on many stations, but according to the other methods, the anomalies are not as significant. The 
difference in number is important. In summer, there are no differences in sign, but, if the magnitude of the change is considered, there are important differences towards the western part of the area, where AN and QM present anomalies that attain $-60 \%$, whereas WT is more moderate. In summer these anomalies are significant in a large area. In autumn there are differences in sign on the Alps, but, as in winter, the differences are not very significant. This is probably due to the fact that September, October, November and December are the months that present more variability.

\section{Discussion and conclusion}

There are many sources of uncertainty in impact studies. The main source is related to the GCM simulation(Boé, 2007), which is often taken into account, but many studies don't take into account the uncertainties related to the final step of downscaling and to the bias-correction of GCM or RCM simulations. In this study, the uncertainties related to this last step were assessed.

Relating precipitation, it was shown that the methods produce similar long term annual averages, but there are important differences. Mainly, the spatial patterns differ. Also, the study shows that the differences between methods depend on the season. For each method, the geographical area where the anomalies are significant is different, reinforcing the idea that these methods are an important source of uncertainty. Nevertheless, these comparisons also show that there are some agreements. According to the RCM simulation used and to the period studied, there might be significant increases of winter precipitation on the Cévennes region of the Massif Central, where present day flash flood are known to be severe, and significant decreases 
of summer precipitation in most of the region, which could reinforce the risk of fire. But, it is not possible to locate the changes with precision, which makes decision making difficult to water managers.

The study of temperature, shows that there are important differences between the methods, specially in summer, where AN and QM are more than one degree warmer. This differences affect many hydrological processes. This is an important source of uncertainty, as there are threshold effects related to this variable.

In terms of evapotranspiration and runoff, the methods present important differences in long term averages over the region. These differences are further propagated to the simulated discharge. For example, in some basins, for some seasons, the methods don't agree in the sign of the anomaly and in basins in which the methods agree in the sign, there are sometimes differences of up to $30 \%$ in the intensity of the anomaly. Therefore, it is not possible to determine the intensity of the anomaly in a specific gauging station, even given the large scale characteristics of the climate change. Nevertheless, some geographical and seasonal patterns emerge. A decrease in the average discharge at the middle of the century is expected in most of the stations for most of the year. Winter and, maybe spring, in some areas, are the exception. Annual discharges may increase in some stations located near the Massif Central. There is more agreement in winter and summer than in autumn and spring. The anomalies are more significant in summer.

The methods QM and WT were developed to better take into account the changes on the extremes, as the AN method is only useful to study the changes on the mean. Nevertheless, the study shows that these methods 
produce also significantly different means

From the methodological point of view, it can be argued that this study overestimates the uncertainty related to the downscaling methods, as it is known that the WT method was not optimized for the Mediterranean region of France, as its area of application was the whole country. Its difficulties to reproduce strong precipitation events on the Cévennes are a good example. Nevertheless, when applying such methods a compromise is always done. Every optimization favors some regions and disfavors other ones. The disfavored regions are usually those where small scale processes are important, like the Mediterranean region of France. Therefore, the authors think that it is worth taking into account this kind of uncertainty. Most studies do not optimize their methods to areas with particularities, and particularities are not rare in the world.

The study shows that the downscaling and bias-correction of the RCM is a crucial step when only one climate model is used to study the impacts of climate change on small basins where many threshold effects are present. Therefore, the selection of methods and the treatment of uncertainties have important effects on the conclusions drawn from the methodology applied, even on annual or seasonal averages. It is expected that the results would be more scattered for the extremes.

Generally, the uncertainty related to the downscaling and bias-correction is lower than the uncertainty related to the emissions scenarios and climate modeling. But more work should be done to analyze if the uncertainties analyzed in this study increase the total uncertainty, when all the uncertainties (emissions scenario, GCM, RCM, downscaling, hydrological model, ...) are 
taken into account. It would also be interesting to focus on the extremes.

A broader conclusion of this work is that impact studies should analyze and explain all the uncertainties related to the methodology used, without neglecting any single step of the procedure. If all the uncertainties can not be explored, the results of the study should be taken with caution, without overselling them. Furthermore, there are also many other sources of uncertainty, which are seldom studied and explained, for example: feedbacks between the changing climate and vegetation, human adaptations to the new climate (changes in agriculture, water management practices, urbanization, etc.) and other human induced changes of the systems, which might be more important than climate change itself. A lot of work is still to be done in the field climate projections and uncertainties, specially in the context of hydrological systems, which are affected by so many external influences.

\section{Acknowledgements}

This work was partly supported by the program ACI-FNS "Aléas et Changements Globaux" of the French research ministry under the project CYPRIM and the French Agence nationale de la recherche under the project MEDUP. The authors are grateful to Joël Noilhan for his continuous support during this research and his previous work, which made this study possible. The authors are also very grateful to the anonymous reviewers whose comments and suggestions helped to improve the clarity of the text.

\section{References}

Boone, A., 2000. Modélisation des processus hydrologiques dans le schéma de surface isba: Inclusion d'un réservoir hydrologique, du gel et modélisation 
de la neige. Ph.D. thesis, Université Paul Sabatier (Toulouse III).

Boone, A., Calvet, J. C., Noilhan, J., 1999. Inclusion of a Third Soil Layer in a Land Surface Scheme Using the Force-Restore Method. Journal of Applied Meteorology 38, 1611-1630.

Boone, A., Etchevers, P., 2001. An intercomparison of three snow schemes of varying complexity coupled to the same land surface model: Local-scale evaluation at an alpine site. Journal of Hydrometeorology 2, 374-394.

Boé, J., 2007. Changement global et cycle hydrologique : Une étude de régionalisation sur la france. $\mathrm{PhD}$ thesis, Université Paul Sabatier (Toulouse III).

Boé, J., Terray, L., Habets, F., Martin, E., 2006. A simple statisticaldynamical downscaling scheme based on weather types and conditional resampling. Journal of Geophysical Research 111 (D23).

Boé, J., Terray, L., Habets, F., Martin, E., 2007. Statistical and dynamical downscaling of the seine basin climate for hydro-meteorological studies. International Journal of Climatology 27 (12), 1643-1655.

Caballero, Y., Voirin-Morel, S., Habets, F., Noilhan, J., LeMoigne, P., Lehenaff, A., Boone, A., Jul. 2007. Hydrological sensitivity of the AdourGaronne river basin to climate change. Water Resources Research 43, W07448.

Christensen, J. H., Boberg, F., Christensen, O. B., Lucas-Picher, P., Oct. 2008. On the need for bias correction of regional climate change projec- 
tions of temperature and precipitation. Geophysical Research Letters 35, L20709.

Christensen, N. S., Lettenmaier, D. P., Jul. 2007. A multimodel ensemble approach to assessment of climate change impacts on the hydrology and water resources of the colorado river basin. Hydrol. Earth Syst. Sci. 11 (4), $1417-1434$

Deardorff, J. W., 1977. A parameterization of ground-surface moisture content for use in atmospheric prediction models. J. Appl. Meteor. 16, 11821185.

Decharme, B., Douville, H., Boone, A., Habets, F., Noilhan, J., 2006. Impact of an exponential profile of saturated hydraulic conductivity within the ISBA LSM: simulations over the rhône basin. Journal of Hydrometeorology $7,61-80$.

Dibike, Y. B., Coulibaly, P., Jun. 2005. Hydrologic impact of climate change in the saguenay watershed: comparison of downscaling methods and hydrologic models. Journal of Hydrology 307 (1-4), 145-163.

Durand, Y., Brun, E., Mérindol, L., Guyomarc'h, G., Lesaffre, B., Martin, E., 1993. A meteorological estimation of relevant parameters for snow models. Ann. Glaciol. 18, 65-71.

Déqué, Rowell, Lüthi, Giorgi, Christensen, Rockel, Jacob, Kjellström, de Castro, van den Hurk, May 2007. An intercomparison of regional climate simulations for europe: assessing uncertainties in model projections. Climatic Change $81(0), 53-70$. 
Etchevers, P., Golaz, C., Habets, F., Noilhan, J., Aug. 2002. Impact of a climate change on the rhone river catchment hydrology. Journal of Geophysical Research 107 (D16), 4293.

Gibelin, A., Déqué, M., 2003. Anthropogenic climate change over the Mediterranean region simulated by a global variable resolution model. Climate Dynamics 20 (4), 327-339.

Giorgi, F., Apr. 2006. Climate change hot-spots. Geophysical Research Letters 33, L08707.

Giorgi, F., Lionello, P., Sep. 2008. Climate change projections for the mediterranean region. Global and Planetary Change 63 (2-3), 90-104.

Habets, F., Boone, A., Champeaux, J. L., Etchevers, P., Franchistéguy, L., Leblois, E., Ledoux, E., Moigne, P. L., Martin, E., Morel, S., Noilhan, J., Quintana Seguí, P., Rousset-Regimbeau, F., Viennot, P., Mar. 2008. The SAFRAN-ISBA-MODCOU hydrometeorological model applied over france. Journal of Geophysical Research 113, D06113.

Habets, F., Boone, A., Noilhan, J., Jul. 2003. Simulation of a scandinavian basin using the diffusion transfer version of ISBA. Global and Planetary Change 38 (1-2), 137-149.

Hamlet, A. F., Lettenmaier, D. P., 1999. Effects of climate change on hydrology and water resources in the Columbia river basin. Journal of the American Water Resources Association 35 (6), 1597-1623.

Hewitson, B., Crane, R., Nov. 1996. Climate downscaling: techniques and application. Climate Research 07 (2), 85-95. 
Jyrkama, M. I., Sykes, J. F., May 2007. The impact of climate change on spatially varying groundwater recharge in the grand river watershed (Ontario). Journal of Hydrology 338 (3-4), 237-250.

Khan, M. S., Coulibaly, P., Dibike, Y., Mar. 2006. Uncertainty analysis of statistical downscaling methods. Journal of Hydrology 319 (1-4), 357-382.

Ledoux, E., Girard, G., de Marsilly, G., Deschenes, J., 1989. Spatially distributed modeling: conceptual approach, coupling surface water and ground water. Kluwer Academic, Dordrecht, pp. 435-454.

Maurer, E. P., Duffy, P. B., Feb. 2005. Uncertainty in projections of streamflow changes due to climate change in california. Geophysical Research Letters 32, L03704.

Maurer, E. P., Hidalgo, H. G., Mar. 2008. Utility of daily vs. monthly largescale climate data: an intercomparison of two statistical downscaling methods. Hydrol. Earth Syst. Sci. 12 (2), 551-563.

Mearns, L. O., Bogardi, I., Giorgi, F., Matyasovszky, I., Palecki, M., 1999. Comparison of climate change scenarios generated from regional climate model experiments and statistical downscaling. Journal of Geophysical Research 104 (D6), 6603-6621.

Minville, M., Brissette, F., Leconte, R., Aug. 2008. Uncertainty of the impact of climate change on the hydrology of a nordic watershed. Journal of Hydrology 358 (1-2), 70-83.

Myers, P., Haines, K., Josey, S., 1998. On the importance of the choice of 
wind stress forcing to the modeling of the Mediterranean Sea circulation. Journal of Geophysical Research 103 (C8).

Nakicenovic, N., Alcamo, J., Davis, G., de Vries, B., Fenhann, J., Gaffin, S., Gregory, K., Grübler, A., Jung, T., Kram, T., La Rovere, E., Michaelis, L., Mori, S., Morita, T., Pepper, W., Pitcher, H., Price, L., Riahi, K., Roehrl, A., Rogner, H.-H., Sankovski, A., Schlesinger, M., Shukla, P., Smith, S., Swart, R., van Rooijen, S., Victor, N., Z., D., 2000. IPCC Special Report on Emissions Scenarios. Cambridge University Press, Cambridge, United Kingdom and New York, NY, USA. 599pp.

Noilhan, J., Planton, S., 1989. A simple parameterization of land surface processes for meteorological models. Monthly Weather Review 117, 536549.

Pagé, C., Terray, L., Boé, J., 2008. Projections climatiques à échelle fine sur la france pour le 21ème siècle : les scénarii SCRATCH08. Technical Report TR/GMGC/08/64, CERFACS, Toulouse, France.

Quintana-Seguí, P., Le Moigne, P., Durand, Y., Martin, E., Habets, F., Baillon, M., Canellas, C., Franchisteguy, L., Morel, S., 2008. Analysis of Near-Surface Atmospheric Variables: Validation of the SAFRAN Analysis over France. Journal of Applied Meteorology and Climatology 47, 92-107.

Quintana Seguí, P., Martin, E., Habets, F., Noilhan, J., Feb. 2009. Improvement, calibration and validation of a distributed hydrological model over france. Hydrol. Earth Syst. Sci. 13 (2), 163-181. 
Ritter, B., Geleyn, J. F., 1992. A comprehensive radiation scheme for numerical weather prediction models with potential applications in climate simulations. Mon. Weather Rev. 120, 303-325.

Solomon, S., Qin, D., Manning, M., Chen, Z., Marquis, M., Averyt, K., Tignor, M., Miller, H., 2007. Climate Change 2007: The Physical Science Basis. Contribution of Working Group I to the Fourth Assessment Report of the Intergovernmental Panel on Climate Change [ (eds.)]. Cambridge University Press, Cambridge, United Kingdom and New York, NY, USA.

Somot, S., 2005. Modélisation climatique du bassin méditerranéen : variabilité et scénarios de changement climatique. Ph.D. thesis, Université Paul Sabatier, Toulouse, France.

Somot, S., Sevault, F., Deque, M., 2006. Transient climate change scenario simulation of the Mediterranean Sea for the 21st century using a highresolution ocean circulation model. Clim. Dyn., 27 (7-9), 851-879.

Somot, S., Sevault, F., Déqué, M., Crepon, M., 2008. 21st century climate change scenario for the mediterranean using a coupled atmosphere-ocean regional climate model. Global and Planetary Change In Press, Accepted Manuscript.

van Roosmalen, L., Sonnenborg, T. O., Jensen, K. H., Mar. 2009. Impact of climate and land use change on the hydrology of a large-scale agricultural catchment. Water Resources Research 43, W07448.

Vrac, M., Stein, M. L., Hayhoe, K., Liang, X., 2007. A general method for 
668

669

670

671

672

673

674

675

676

677

678

validating statistical downscaling methods under future climate change 34, L18701.

Welch, B. L., 1947. The generalization of "student's" problem when several different population variances are involved. Biometrika 34 (1-2), 28-35.

Wilby, R., Whitehead, P., Wade, A., Butterfield, D., Davis, R., Watts, G., Oct. 2006. Integrated modelling of climate change impacts on water resources and quality in a lowland catchment: River kennet, UK. Journal of Hydrology 330 (1-2), 204-220.

Wood, Leung, Sridhar, Lettenmaier, 2004. Hydrologic implications of dynamical and statistical approaches to downscaling climate model outputs. Climatic Change 62 (1), 189-216. 


\section{List of Figures}

1 Topographical map of the area of study. . . . . . . . . . . . 34

2 Mean annual precipitation $\left(\mathrm{mm} \mathrm{d}^{-1}\right)$ and temperature $\left({ }^{\circ} \mathrm{C}\right)$ in the area of study for the period 1970-2000 as reproduced by the SAFRAN meteorological analysis. . . . . . . . . . . 35

3 Differences between the WT downscaling method and the SAFRAN database of observations for the period 1970-2000 (in $\mathrm{mm} \mathrm{d}^{-1}$ ). 36

4 Panel (a) shows the distribution of the intensities of precipitation in $\mathrm{mm} \mathrm{d}^{-1}$. Panels (b) and (c) show the lengths of dry and wet spells. A day is dry if daily precipitation is equal to zero, otherwise it is wet. In both cases the probability is calculated using all the grid cells of the area of interest. SFR corresponds to SAFRAN, QM to the quantile mapping downscaling method and, finaly WT corresponds to the weather typing method. . . . . . . . . . . . . . . . 37

5 First row: anomalies of average annual precipitation obtained with the same RCM and different downscaling methods. Second row: significance of the anomalies: dark gray means that the changes are statistically significant, and light gray means they are not. The anomalies are calculated comparing two periods: 2035-2065 vs 1970-2000. . . . . . . . . . . . 38

6 Comparison of the anomalies of precipitation (2035-2065 vs 1970-2000) produced, for winter and summer, by three different downscaling methods. . . . . . . . . . . . . . . . 39

$7 \quad$ Significance of the anomalies of mean seasonal precipitation. Dark gray means that the changes are statistically significant, and light gray means they are not. The anomalies are calculated comparing two periods: $2035-2065$ vs $1970-2000$. . . . . 40

8 Histograms of the number of stations in each class of anomaly of discharge according to the three different downscaling methods. . . . . . . . . . . . . . . . . . 4 41

9 First row: anomalies of average annual discharge obtained with the same RCM and different downscaling methods. Second row: significance of the anomalies: black means that the changes are statistically significant, and light gray means they are not. The anomalies are calculated comparing two periods: 2035-2065 vs 1970-2000. . . . . . . . . . . . . . 42 
10 Comparison of the anomalies of discharge (2035-2065 vs 19702000) produced, for two seasons, by three different downscaling methods. . . . . . . . . . . . . . . . . . . 43

11 Significance of the anomalies of mean seasonal discharge. Black means that the changes are statistically significant, and light gray means they are not. The anomalies are calculated comparing two periods: $2035-2065$ vs 1970-2000 . . . . . . . . . . 44 


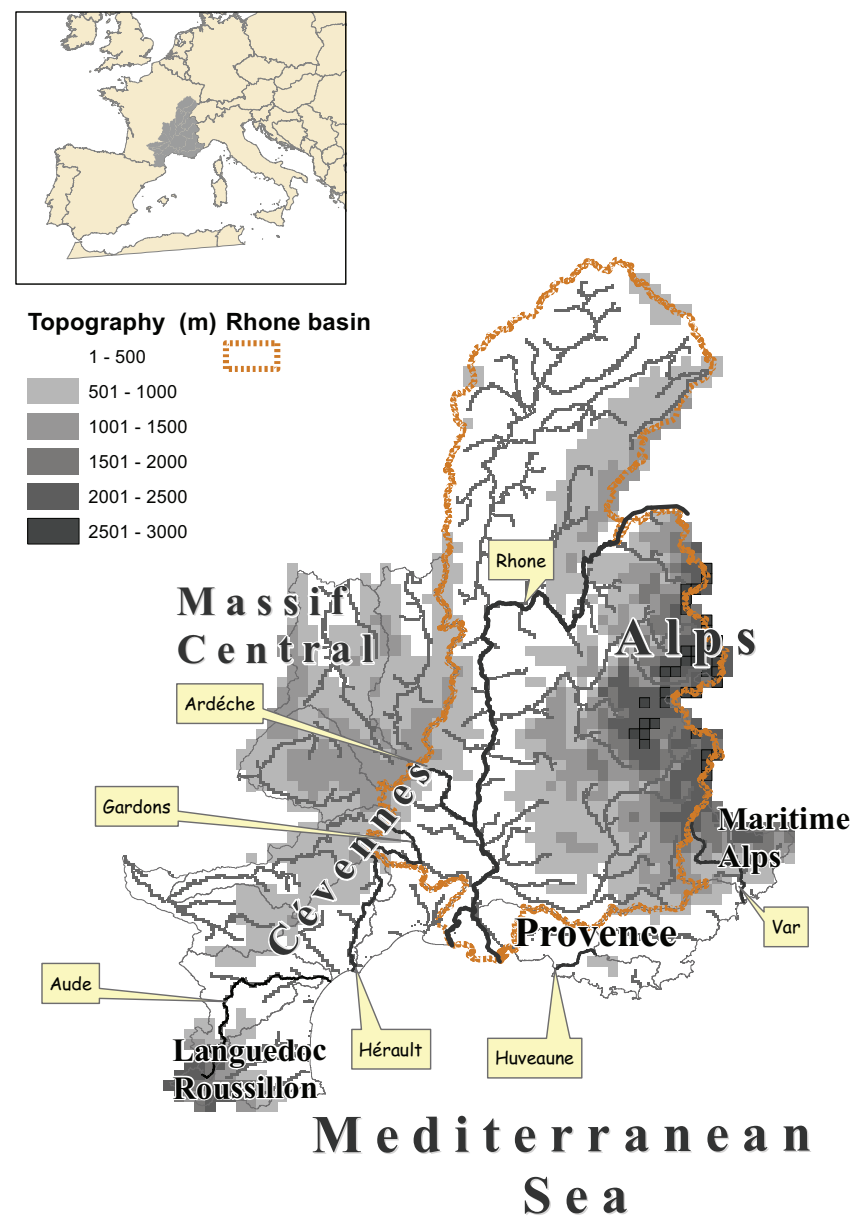

Figure 1: Topographical map of the area of study. 


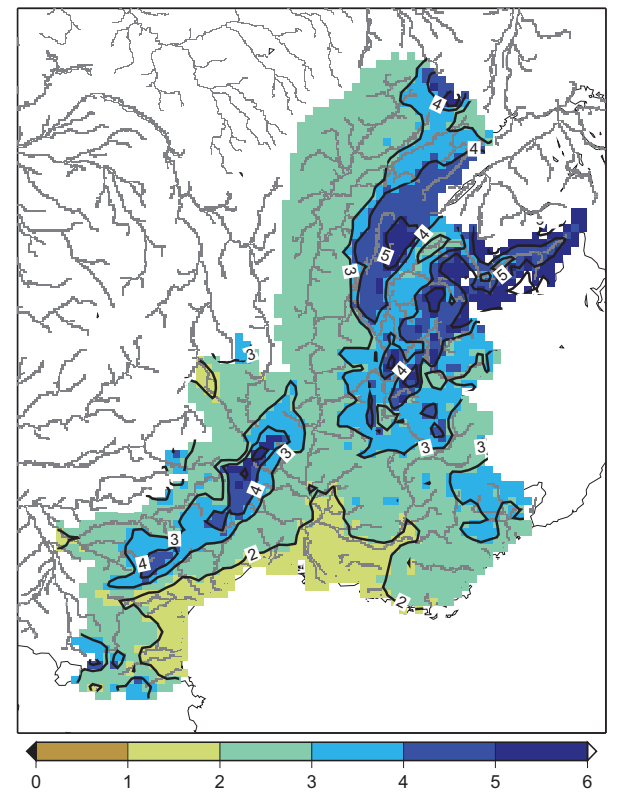

(a) Precipitation

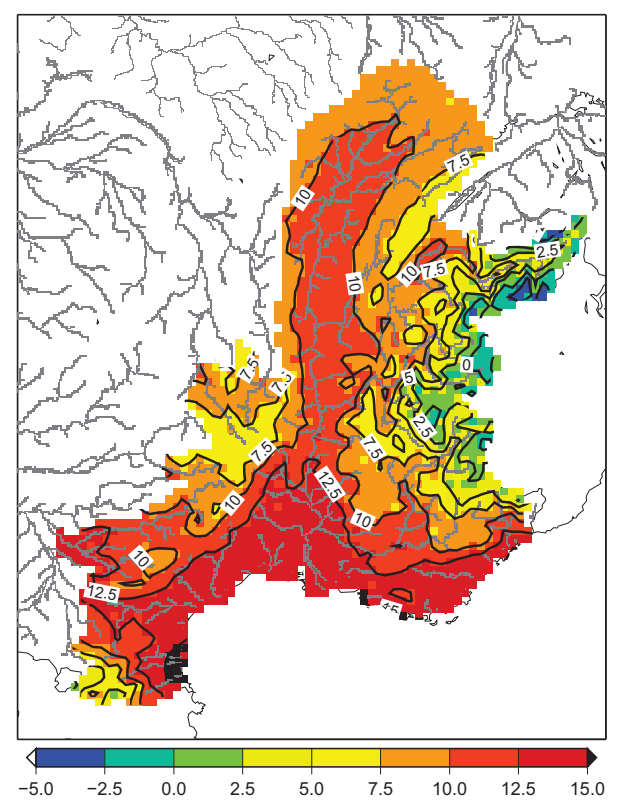

(b) Temperature

Figure 2: Mean annual precipitation $\left(\mathrm{mm} \mathrm{d}^{-1}\right)$ and temperature $\left({ }^{\circ} \mathrm{C}\right)$ in the area of study for the period 1970-2000 as reproduced by the SAFRAN meteorological analysis. 


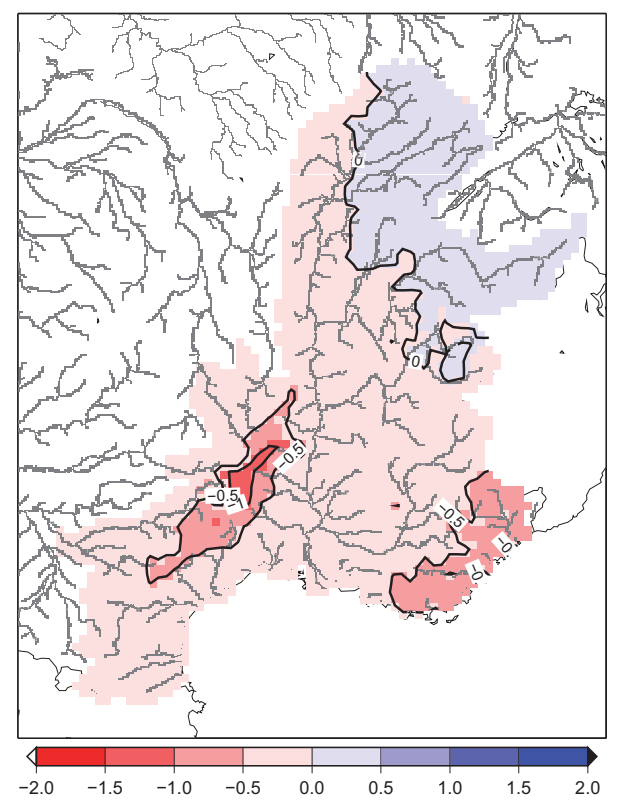

(a) Precipitation

Figure 3: Differences between the WT downscaling method and the SAFRAN database of observations for the period 1970-2000 (in $\mathrm{mm} \mathrm{d}^{-1}$ ). 


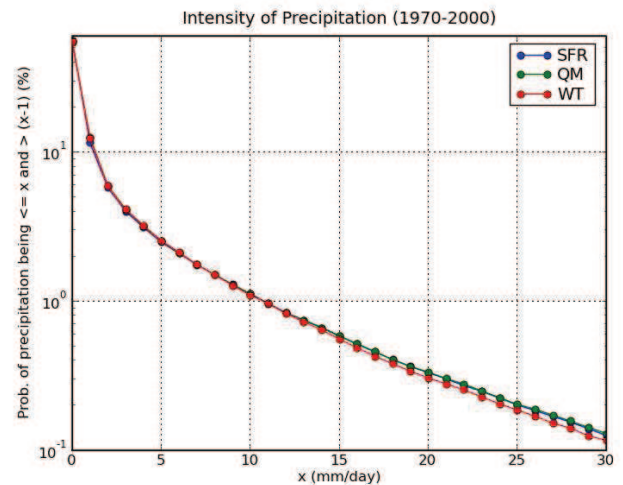

(a)

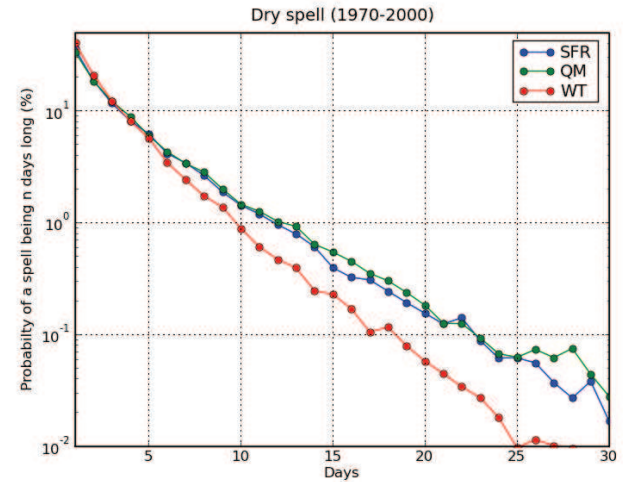

(b)

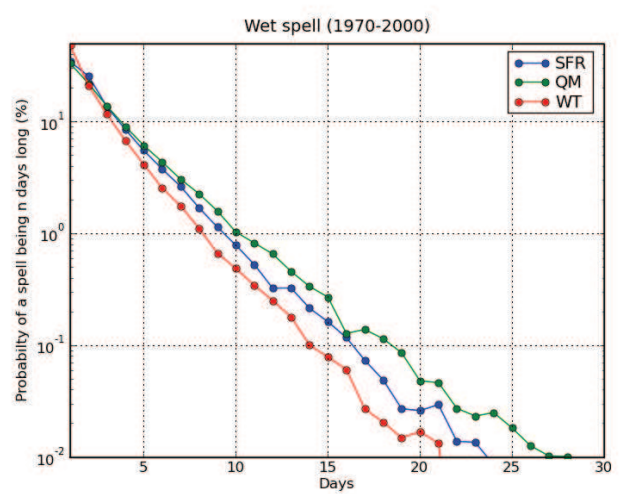

(c)

Figure 4: Panel (a) shows the distribution of the intensities of precipitation in $\mathrm{mm} \mathrm{d}^{-1}$. Panels (b) and (c) show the lengths of dry and wet spells. A day is dry if daily precipitation is equal to 3 zero, otherwise it is wet. In both cases the probability is calculated using all the grid cells of the area of interest. SFR corresponds to SAFRAN, QM to the quantile mapping downscaling method and, finaly WT corresponds to the weather typing method. 


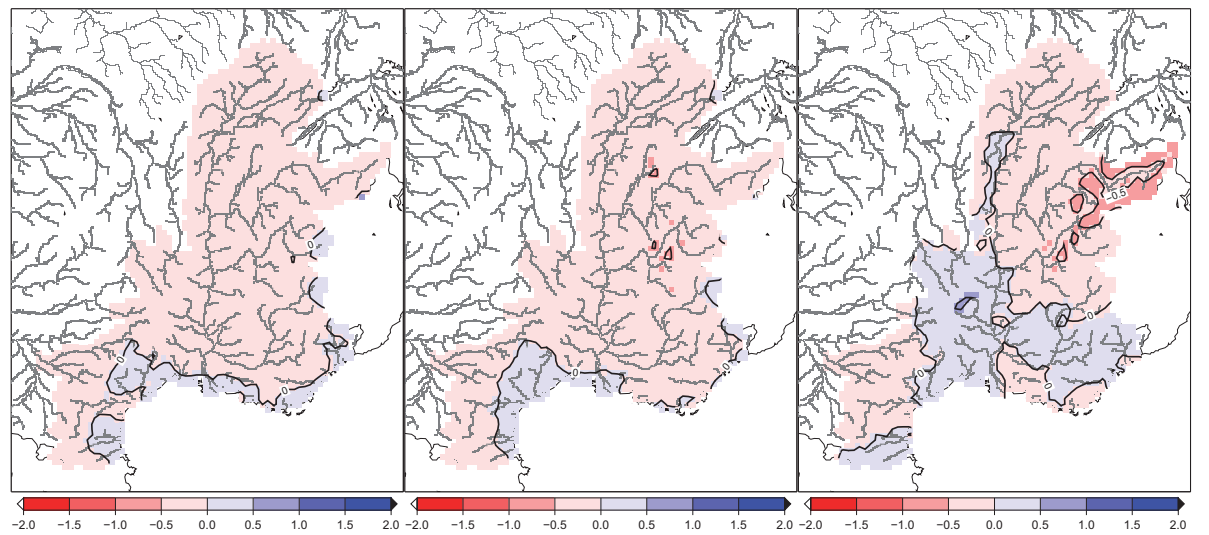

(a) $\mathrm{AN}$

(b) QM

(c) WT

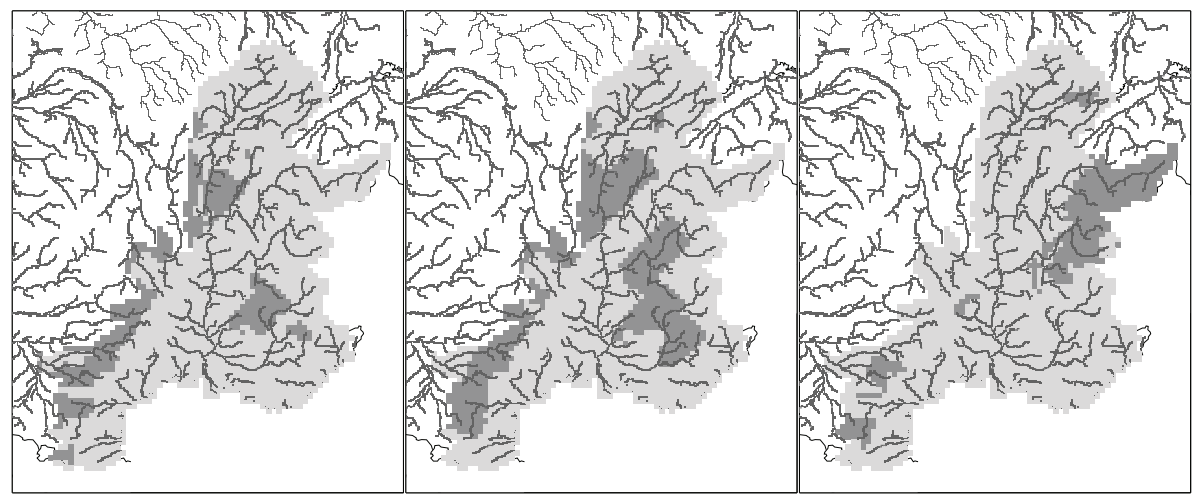

(d) $\mathrm{AN}$

(e) QM

(f) WT

Figure 5: First row: anomalies of average annual precipitation obtained with the same RCM and different downscaling methods. Second row: significance of the anomalies: dark gray means that the changes are statistically significant, and light gray means they are not. The anomalies are calculated comparing two periods: 2035-2065 vs 1970-2000. 


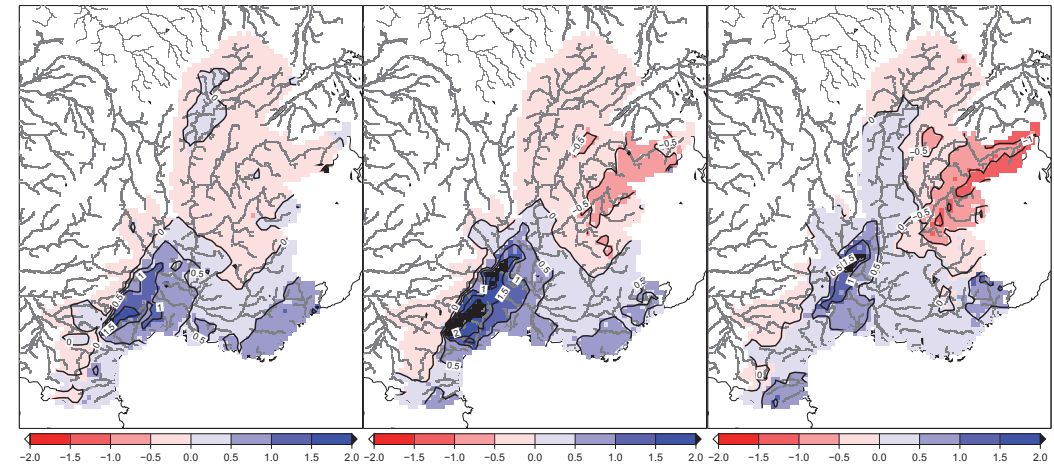

(a) AN DJF

(b) QM DJF

(c) WT DJF

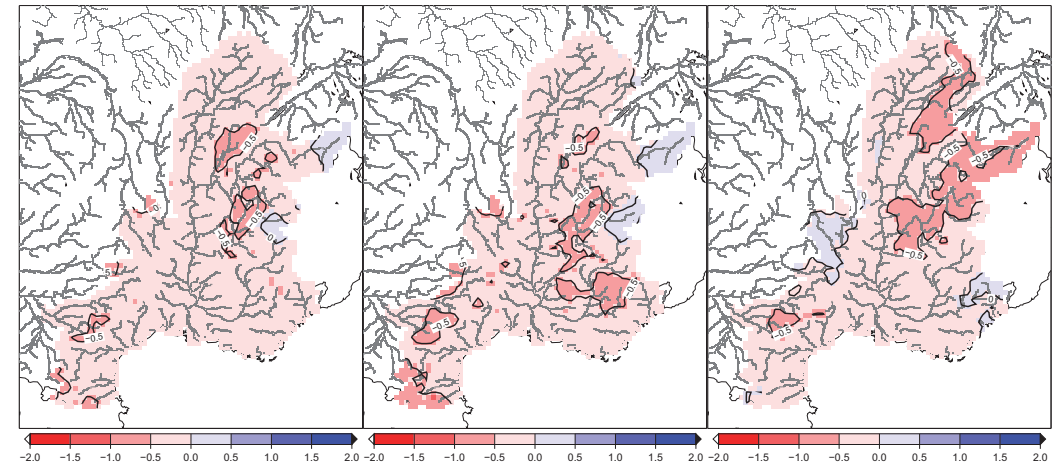

(d) AN JJA

(e) QM JJA

(f) WT JJA

Figure 6: Comparison of the anomalies of precipitation (2035-2065 vs 19702000) produced, for winter and summer, by three different downscaling methods. 


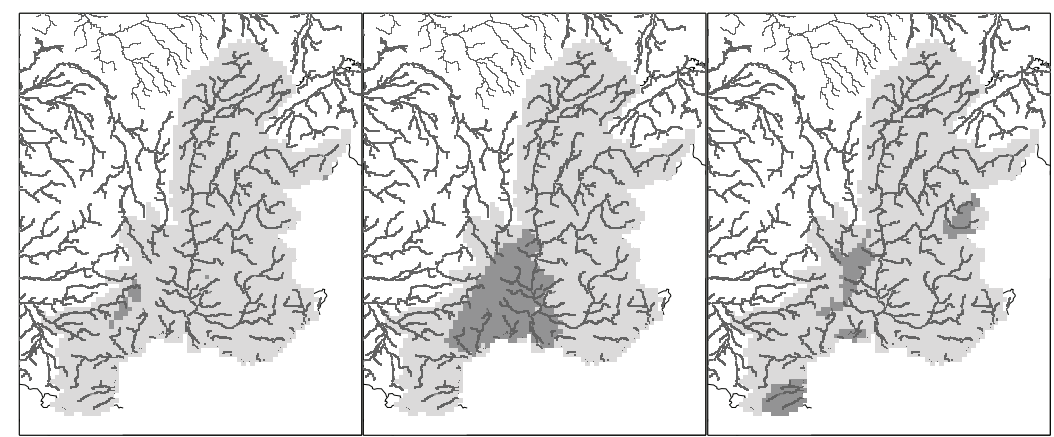

(a) AN DJF

(b) QM DJF

(c) WT DJF

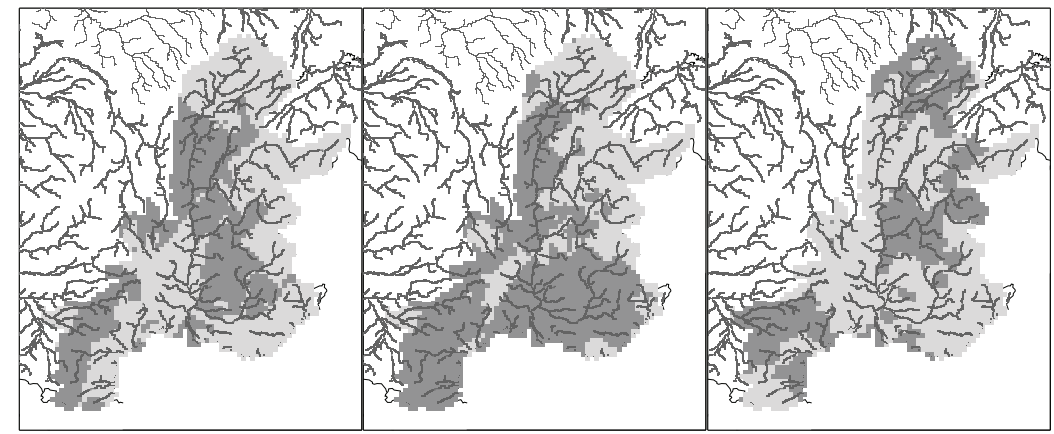

(d) AN JJA

(e) QM JJA

(f) WT JJA

Figure 7: Significance of the anomalies of mean seasonal precipitation. Dark gray means that the changes are statistically significant, and light gray means they are not. The anomalies are calculated comparing two periods: 20352065 vs $1970-2000$. 

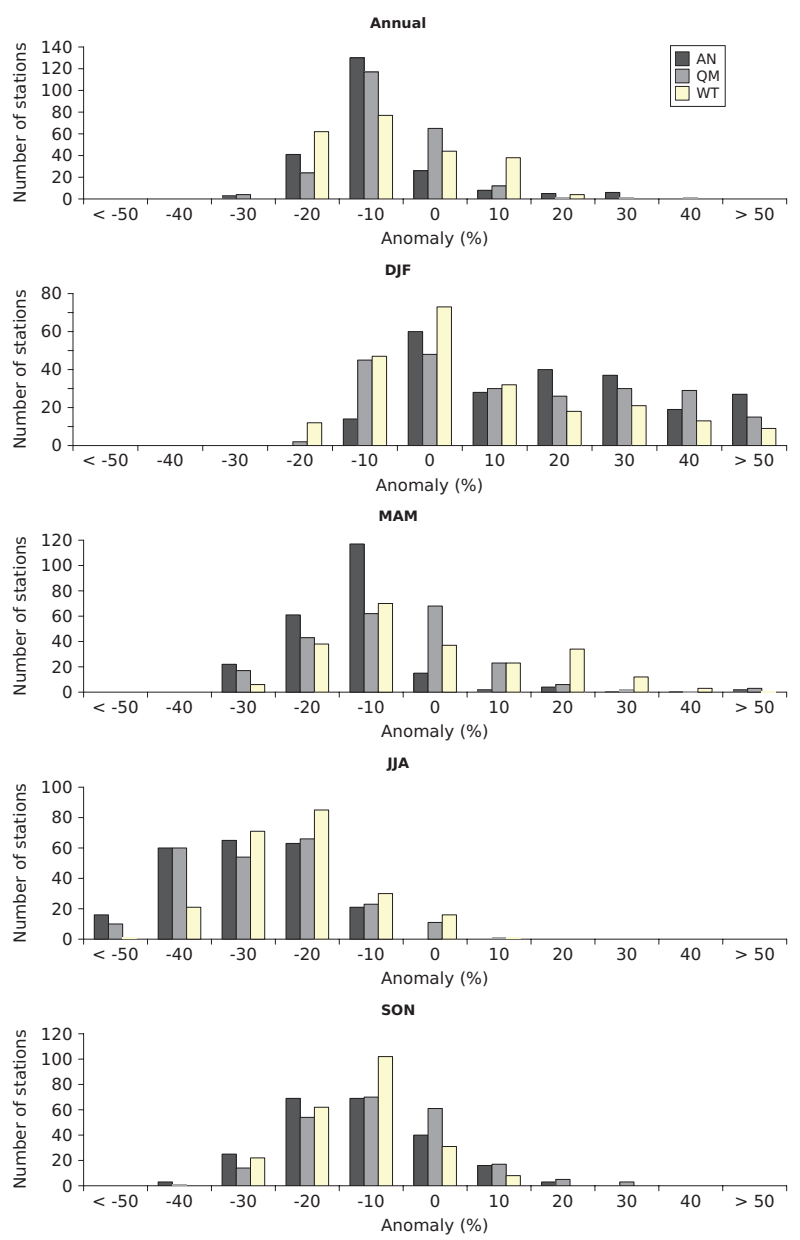

Figure 8: Histograms of the number of stations in each class of anomaly of discharge according to the three different downscaling methods. 


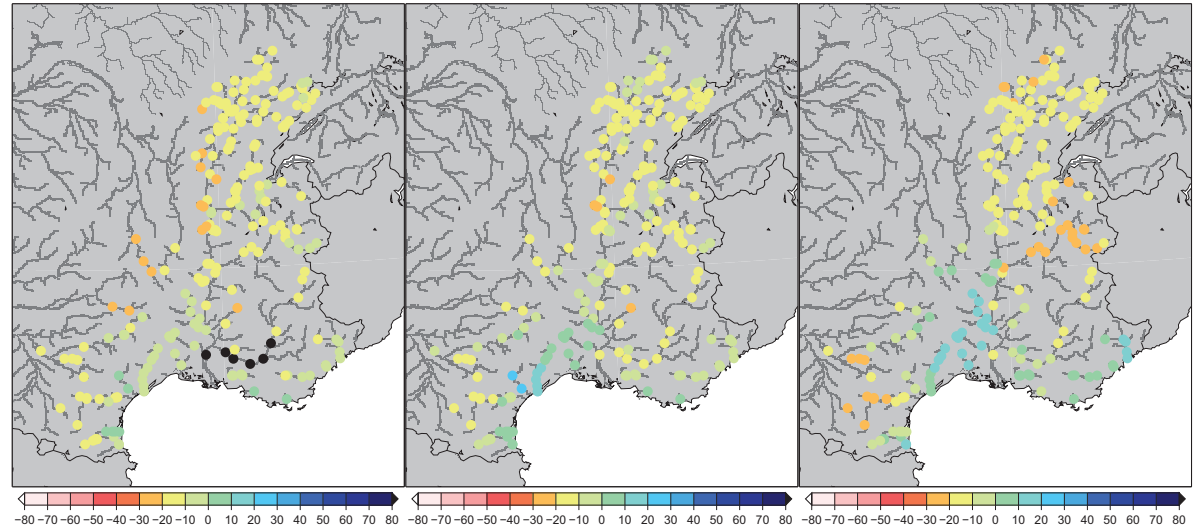

(a) AN YEAR

(b) QM YEAR

(c) WT YEAR

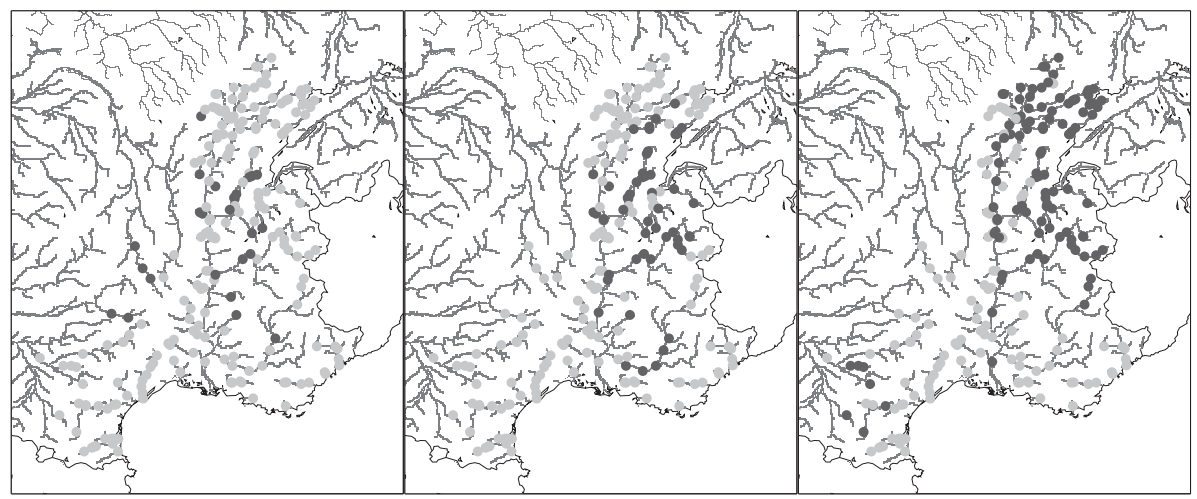

(d) AN YEAR

(e) QM YEAR

(f) WT YEAR

Figure 9: First row: anomalies of average annual discharge obtained with the same RCM and different downscaling methods. Second row: significance of the anomalies: black means that the changes are statistically significant, and light gray means they are not. The anomalies are calculated comparing two periods: $2035-2065$ vs 1970-2000. 


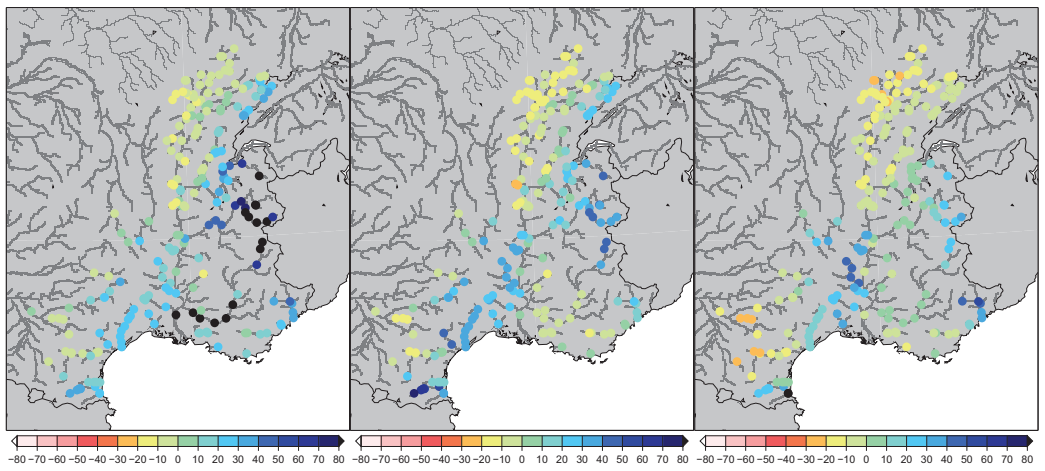

(a) AN DJF

(b) QM DJF

(c) WT DJF

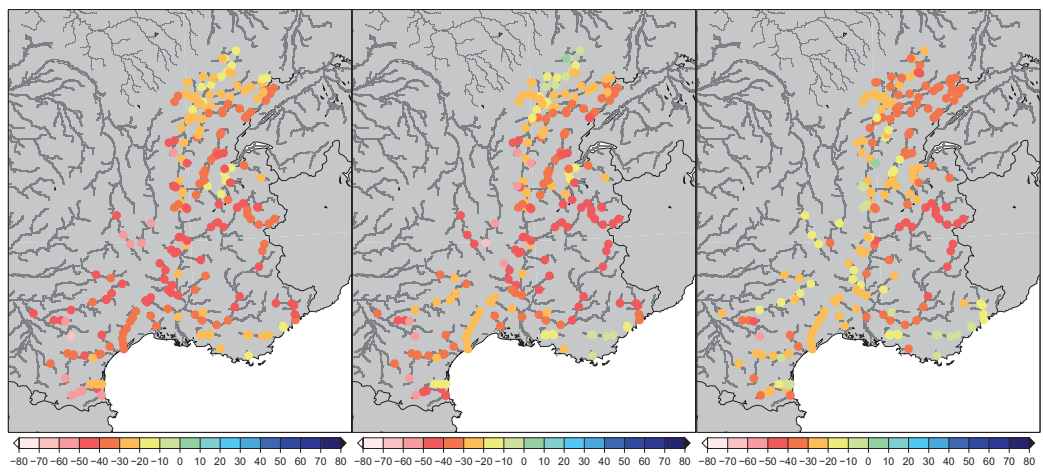

(d) AN JJA

(e) QM JJA

(f) WT JJA

Figure 10: Comparison of the anomalies of discharge (2035-2065 vs 19702000) produced, for two seasons, by three different downscaling methods. 


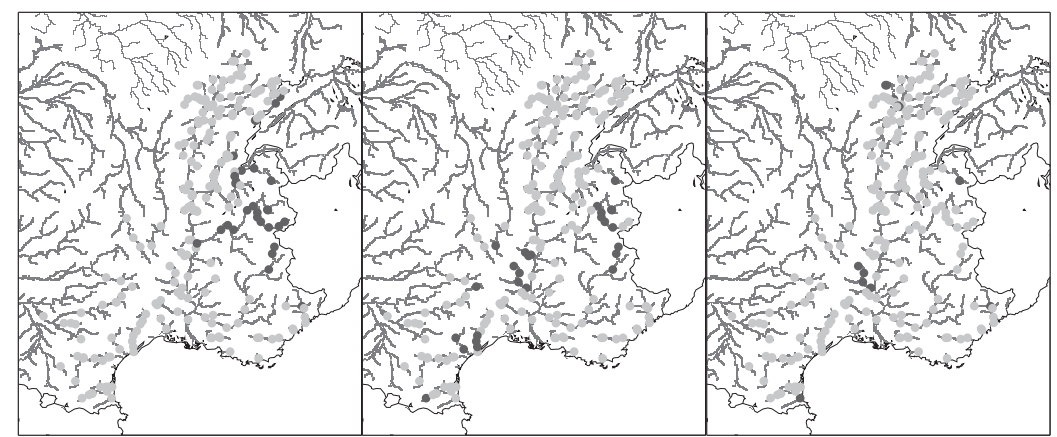

(a) AN DJF

(b) QM DJF

(c) WT DJF

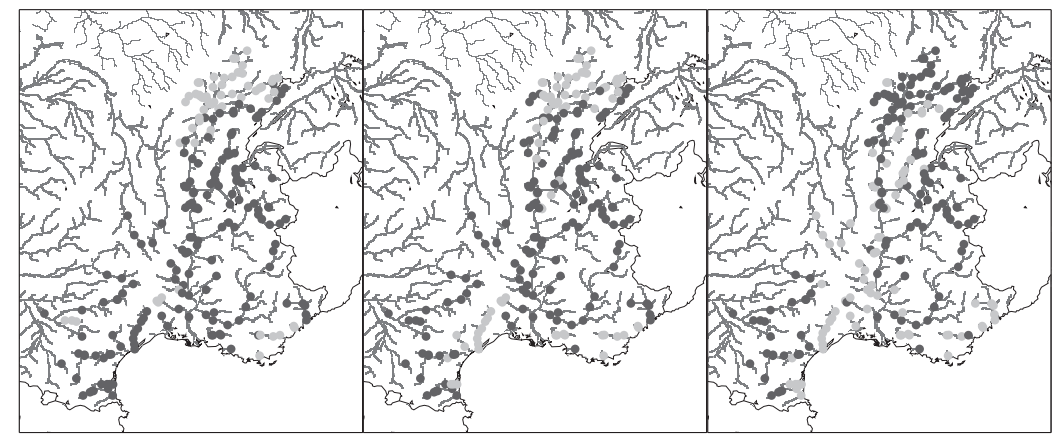

(d) AN JJA

(e) QM JJA

(f) WT JJA

Figure 11: Significance of the anomalies of mean seasonal discharge. Black means that the changes are statistically significant, and light gray means they are not. The anomalies are calculated comparing two periods: 2035-2065 vs 1970-2000. 


\section{List of Tables}

1 Average precipitation $\left(\mathrm{mm} \mathrm{d}^{-1}\right)$, temperature $\left({ }^{\circ} \mathrm{C}\right)$, total runoff $\left(\mathrm{mm} \mathrm{d}^{-1}\right)$ and evapotranspiration $\left(\mathrm{mm} \mathrm{d}^{-1}\right)$ on the Mediterranean region of France for the end of the 20th century and the middle of the 21st and their corresponding anomalies. SFR corresponds to the SAFRAN gridded database, QM to the quantile mapping method, WT to weather typing and AN to the method of the anomaly. . . . . . . . . . . . . 46 


\begin{tabular}{|c|c|c|c|c|c|c|c|c|c|c|c|c|}
\hline & \multicolumn{3}{|c|}{ Precipitation } & \multicolumn{3}{|c|}{ Temperature } & \multicolumn{3}{|c|}{ Total Runoff } & \multicolumn{3}{|c|}{ Evapotranspiration } \\
\hline & \multicolumn{12}{|c|}{$1970-2000$} \\
\hline & $\begin{array}{l}\text { SFR } \\
\end{array}$ & QM & $\begin{array}{l}\mathrm{WT} \\
\end{array}$ & $\begin{array}{l}\text { SFR } \\
\end{array}$ & QM & $\overline{\mathrm{WT}}$ & SFR & $\mathrm{QM}$ & $\begin{array}{l}\mathrm{WT} \\
\end{array}$ & SFR & $\mathrm{QM}$ & WT \\
\hline Year & 3.0 & 3.0 & 2.8 & 9.3 & 8.9 & 9.7 & 1.6 & 1.5 & 1.3 & 1.4 & 1.6 & 1.6 \\
\hline DJF & 3.1 & 3.1 & 2.9 & 2.2 & 1.6 & 2.2 & 1.9 & 1.9 & 1.5 & 0.3 & 0.4 & 0.5 \\
\hline MAM & 2.9 & 2.9 & 2.8 & 8.0 & 7.7 & 8.4 & 2.0 & 1.8 & 1.5 & 1.7 & 1.9 & 1.9 \\
\hline JJA & 2.5 & 2.5 & 2.4 & 17.1 & 17.0 & 17.9 & 1.4 & 1.2 & 1.2 & 2.8 & 2.8 & 2.7 \\
\hline \multirow[t]{3}{*}{ SON } & 3.5 & 3.5 & 3.2 & 9.7 & 9.4 & 10.1 & 1.3 & 1.2 & 0.9 & 1.0 & 1.1 & 1.1 \\
\hline & \multicolumn{12}{|c|}{$2035-2065$} \\
\hline & $\mathrm{AN}$ & $\overline{\mathrm{QM}}$ & WT & $\mathrm{AN}$ & QM & $\mathrm{WT}$ & $\mathrm{AN}$ & $\mathrm{QM}$ & $\begin{array}{l}\mathrm{WT} \\
\end{array}$ & $\mathrm{AN}$ & $\mathrm{QM}$ & WT \\
\hline Year & 2.9 & 2.9 & 2.7 & 10.8 & 10.6 & 11.2 & 1.5 & 1.3 & 1.2 & 1.5 & 1.5 & 1.6 \\
\hline DJF & 3.3 & 3.2 & 2.8 & 3.7 & 3.4 & 3.9 & 2.1 & 1.9 & 1.5 & 0.3 & 0.5 & 0.5 \\
\hline MAM & 2.7 & 2.7 & 2.7 & 9.3 & 9.1 & 9.7 & 1.7 & 1.6 & 1.4 & 1.8 & 2.0 & 2.2 \\
\hline JJA & 2.2 & 2.1 & 2.1 & 19.3 & 19.2 & 19.3 & 1.0 & 0.8 & 0.8 & 2.7 & 2.5 & 2.5 \\
\hline \multirow[t]{3}{*}{ SON } & 3.3 & 3.4 & 3.2 & 11.0 & 10.7 & 11.7 & 1.1 & 1.0 & 0.8 & 1.0 & 1.0 & 1.2 \\
\hline & \multicolumn{12}{|c|}{ Difference } \\
\hline & $\overline{\mathrm{AN}}$ & $\overline{\mathrm{QM}}$ & $\overline{\mathrm{WT}}$ & $\mathrm{AN}$ & $\mathrm{QM}$ & $\overline{W T}$ & $\mathrm{AN}$ & $\mathrm{QM}$ & $\begin{array}{l}\mathrm{WT} \\
\end{array}$ & $\mathrm{AN}$ & $\mathrm{QM}$ & $\begin{array}{l}\mathrm{WT} \\
\end{array}$ \\
\hline Year & $-3 \%$ & $-3 \%$ & $-4 \%$ & +1.5 & +1.7 & +1.5 & $-6 \%$ & $-13 \%$ & $-8 \%$ & $+7 \%$ & $-6 \%$ & $0 \%$ \\
\hline DJF & $+6 \%$ & $+3 \%$ & $-3 \%$ & +1.5 & +1.8 & +1.7 & $+11 \%$ & $0 \%$ & $0 \%$ & $0 \%$ & $+25 \%$ & $0 \%$ \\
\hline MAM & $-7 \%$ & $-7 \%$ & $-4 \%$ & +1.3 & +1.4 & +1.3 & $-15 \%$ & $-11 \%$ & $-7 \%$ & $+6 \%$ & $+5 \%$ & $+16 \%$ \\
\hline JJA & $-12 \%$ & $-16 \%$ & $-13 \%$ & +2.2 & +2.2 & +1.4 & $-29 \%$ & $-33 \%$ & $-33 \%$ & $-4 \%$ & $-11 \%$ & $-7 \%$ \\
\hline $\mathrm{SON}$ & $-6 \%$ & $-3 \%$ & $0 \%$ & +1.3 & +1.3 & +1.6 & $-15 \%$ & $-17 \%$ & $-11 \%$ & $0 \%$ & $-9 \%$ & $+9 \%$ \\
\hline
\end{tabular}

Table 1: Average precipitation $\left(\mathrm{mm} \mathrm{d}^{-1}\right)$, temperature $\left({ }^{\circ} \mathrm{C}\right)$, total runoff $\left(\mathrm{mm} \mathrm{d}^{-1}\right)$ and evapotranspiration $\left(\mathrm{mm} \mathrm{d}^{-1}\right)$ on the Mediterranean region of France for the end of the 20th century and the middle of the 21st and their corresponding anomalies. SFR corresponds to the SAFRAN gridded database, QM to the quantile mapping method, WT to weather typing and AN to the method of the anomaly. 